\title{
PENINGKATAN KEMAMPUAN GURU BAHASA INGGRIS SMP NEGERI 2 TEBINGTINGGI DALAM MELAKSANAKAN PEMBELAJARAN CONTEKTUAL TEACHING AND LEARNING MELALUI KEGIATAN SUPERVISI KLINIS
}

\author{
Sinur Hutagaol \\ Surel: sinurhutagaol@gmail.com
}

\begin{abstract}
The purpose of this study is to improve the ability of English teachers in conducting the learning process that uses the concept of contextual learning. This study uses Kemmis M Targart research, consisting of 2 cycles in which each cycle consists of activities of planning, implementation, observation and reflection. Data collection techniques in this study are using interviews, observations and questionnaires. This research is said to be successful because of the pre cycle where from the samples taken, from five teachers who were guided by researchers, not one person has ever applied contextual learning in teaching. The success rate of this study is $88.8 \%$. Based on the results of these studies then through clinical supervision activities can increase teacher commitment in implementing learning Contextual teaching and Learning and this research is said to be successful.
\end{abstract}

Keywords: Ability, CTL, Clinical Supervision

\begin{abstract}
ABSTRAK
Tujuan dari penelitian ini adalah untuk meningkatkan kemampuan guru bahasa Inggris dalam melakukan proses pembelajaran yang menggunakan konsep pembelajaran kontekstual. Penelitian ini menggunakan penelitian Kemmis M Targart, terdiri dari 2 siklus dimana setiap siklusnya terdiri dari kegiatan perencanaan, pelaksanaan, observasi dan refleksi.Teknik pengumpulan data pada penelitian ini adalah menggunakan wawancara, observasi dan angket. Penelian ini dikatakan berhasil karena dari pra siklus dimana dari sampel yang diambil, dari lima orang guru yang menjadi binaan peneliti, tidak satu orangpun yang pernah menerapkan pembelajaran kontekstual dalam pembeelajarannya. Tingkat keberhasilan penelitian ini adalah $88,8 \%$. Berdasarkan hasil penelitian tersebut maka melalui kegiatan supervise klinis dapat meningkatkan komitmen guru dalam menerapkan pembelajaran Contextual teaching and Learning dan penelitian ini dikatakan berhasil.
\end{abstract}

Kata Kunci : Kemampuan, CTL, Supervise Klinis

\section{PENDAHULUAN}

Pendidikan yang berkualitas merupakan cita cita yang ingin dicapai oleh bangsa Indonesia. Agar pendidikan berkualitas dapat terwujud maka diperlukan sistem pembelajaran yang berkualitas.
Pendidikan berkualitas menuntut guru mampu menggunakan berbagai metode pembelajaran yang tepat dan efektif di dalam kelas. Proses pembelajaran di dalam kelas, pada dasarnya dimaksudkan untuk membantu siswa bertahan hidup atau 
bahkan mewarnai kehidupan. Bahkan dalam lingkup secara luas, menurut Hamalik (2003:61-64) pembelajaran adalah (1) upaya mengorganisasi lingkungan untuk menciptakan kondisi belajar bagi siswa, (2) upaya mempersiapkan siswa untuk menjadi warga masyarakat yang baik, dan (3) suatu proses membantu siswa dalam menghadapi kehidupan masyarakat sehari-hari.

SMP Negeri 2 kota Tebing Tinggi merupakan sekolah yang menjadi salah satu tempat peneliti bertugas sebagai pengawas sekolah. Sudah lebih lima tahun peneliti bertugas sebagai pengawas yang bertugas memberikan bimbingan edukatif bagi kepala sekolah dan membina guru-guru bahasa Inggris yang berada di sekolah tersebut. Pengalaman peneliti sebagai pengawas sekolah yang membina SMP Negeri 2 ini, menunjukkan bahwa setidaknya sampai dengan akhir tahun 2016 sebagian besar dari guru cenderung masih menerapkan pembelajaran konvensional, meskipun sudah mengikuti pelatihan/ workshop Contextual Teaching and Learning (CTL), bahkan juga bagii guru-guru yang telah lulus sertifikasi tidak terlihat perbedaan yang signifikan dalam hal menciptakan proses pebelajaran aktif dalam kegiatan belajar mengajar yang diampuhnya.

Peneliti selaku pengawas sekolah menyadari bahwa proses pembelajaran yang demikian itu dirasa kurang efektif dilakukan dimasa sekarang ini, untuk itu peneliti telah melakukan upaya agar para guru dapat menerapkan CTL dalam proses pembelajarannya dengan cara memberikan kesempatan kepada guru untuk mengikuti pelatihan/workshop di tingkat kabupaten dan provinsi, serta melaksanakan pelatihan/workshop CTL di sekolah dengan mengundang nara sumber perguruan tinggi.

Dari sebanyak lima orang guru yang mengajar bahasa Inggris di SMP Negeri 2 kota Tebingtinggi, hanya 1 orang (20\%) guru saja yang memiliki komitmen untuk menerapkannya pembelajaran contextual teaching and learning di dalam kelas itupun belum optimal. Sedangkan, 4 orang (80\%) belum mau mencoba dan masih cenderung kembali menerapkan pembelajaran konvensional yang ditandai dengan (1) pembelajaran monoton, metode yang digunakan tidak bervariasi, dan metode ceramah sebagai primadonanya, (2) pembelajaran berpusat pada guru (teacher centered), (3) guru dan buku dominan bahkan merupakan sumber belajar utama, (4) sangat minim dalam penggunaan media pembelajaran/alat peraga, (5 pertanyaan/tugas yang diajukan/diberikan guru cenderung hanya mengarahkan siswa sekedar mengulang gagasan yang telah disampaikan guru dengan tingkat pertanyaan/tugas hanya terbatas pada pertanyaan tingkat rendah dan sedang saja. 
Keadaan yang demikian itu, tidaklah dapat dibiarkan saja. Kondisi proses pembelajaran yang konvensional akan membuat siswa sulit mengembangkan segala potensi yang dimilikinya. Siswa akan terbiasa menerima penjelasan dari guru tanpa pernah coba untuk mengeksplore segala potensi yang terdapat di dalam dirinya melalui kegiatan-kegiatan yang menantang. Kegiatan seperti ini harus segera diperbaiki agar kemampuan siswa dapat lebih meningkat sehingga berdampak pada kualitas dan hasil proses belajar mengajar di seluruh kelas yang terdapat di SMP Negeri 2 kota Tebingtinggi.

Supervisi klinis merupakan satu strategi yang bisa coba diterapkan oleh pengawas sekolah dalam upaya merubah karakter guru dalam melaksanakan proses belajar mengajar. Supervisi klinis dilakukan pengawas sekolah terhadap seluruh guru bahasa Inggris yang berada di SMP negeri 2 kota Tebingtinggi disaat proses belajar mengajar berlangsung.

Dari latar belakang di atas, peneliti melakukan penelitian ini dengan tujuan untuk meningkatkan kemampuan guru bahasa Inggris dalam melakukan proses pembelajaran yang menggunakan konsep pembelajaran kontekstual.

\section{METODE PENELITIAN}

Penelitian ini dilakukan di SMP Negeri 2 jalan Imam Bonjol Kota Tebing Tinggi. Subjek penelitian adalah guru guru bahasa
Inggris SMP Negeri 2 yang berjumlah 5 orang yang menjadi binaan peneliti dengan rincian 2 lakilaki dan 3 perempuan. Keseluruhan guru yang menjadi subjek penelitian adalah guru guru yang menjadi binaan peneliti yang mengajar di kelas VII, VIII, dan IX SMP Negeri 2 kota Tebingtinggi. Objek dari penelitian ini adalah: (a) kemampuan guru dalam merancang proses belajar mengajar yang menerapkan pembelajaran Contextual Teaching and Learning (CTL) (b) kemampuan guru dalam mengelola pembelajaran menggunakan 7 komponen CTL sebagai perwujudan pelaksanaan pembelajaran Contextual Teaching and Learning (CTL).

Penelitian ini adalah penelitian tindakan sekolah (PTS), yang terdiri dari 2 siklus. Sesuai dengan jenis penelitian yang dipilih, yaitu penelitian tindakan, maka penelitian ini menggunakan model penelitian tindakan dari Kemmis dan Taggart (dalam Sugiarti, 1997: 6), yaitu berbentuk spiral dari siklus yang satu ke siklus yang berikutnya. Setiap siklus meliputi planning (rencana), action (tindakan), observation (pengamatan), dan reflection (refleksi). Langkah pada siklus berikutnya adalah perncanaan yang sudah direvisi, tindakan, pengamatan, dan refleksi. Sebelum masuk pada siklus 1 dilakukan tindakan pendahuluan yang berupa identifikasi permasalahan. Siklus spiral dari tahap-tahap penelitian tindakan kelas dapat dilihat pada gambar berikut: 


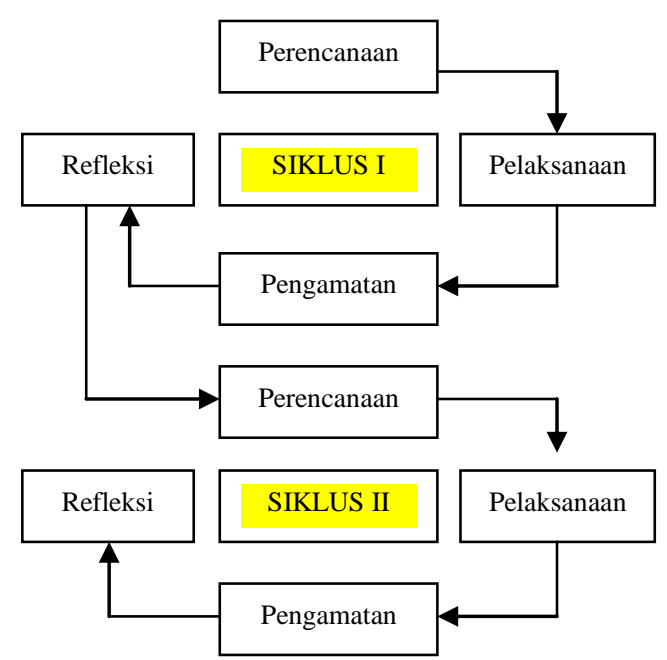

Gambar 1. Model Alur PTK

Teknik dan Alat Pengumpulan Data Teknik

a. Wawancara dipergunakan untuk mendapatkan data atau informasi tentang pemahaman guru terhadap pembelajaran yang menerapkan Contextual Teaching and Learning (CTL)

b. Observasi dipergunakan untuk mengumpulkan data dan mengetahui kompetensi guru dalam mengajar yang menerapkan pembelajaran Contextual Teaching and Learning (CTL)

c. Angket yang bertujuan untuk mengetahui bagaimana pendapat siswa terhadap proses pembelajaran yang dilakukan oleh guru.

\section{Alat Pengumpulan Data}

a. Wawancara menggunakan panduan wawancara yang dipersiapkan oleh peneliti yang bertujuan untuk mengetahui kemampuan awal yang dimiliki guru tentang pembelajaran

Contextual Teaching and Learning (CTL)

b. Observasi menggunakan lembar observasi.

c. Angket berisi pertanyaan yang bertujuan untuk melihat respon siswa terhadap proses pembelajaran Contextual Teaching and Learning (CTL) yang dilaksanakan oleh guru.

\section{Indikator keberhasilan}

a. Hasil rata rata pencapaian guru yang didampingi dalam penerapan 7 komponen CTL dalam proses pembelajaran diatas $85 \%$

\section{HASIL PENELITIAN DAN PEMBAHASAN}

Siklus I

Siklus pertama terdiri dari empat tahap yakni: (1) perencanaan, (2) pelaksanaan, (3) observasi, dan (4) refleksi seperti berikut ini.

Peneliti melakukan kegiatan awal supervisi klinis dengan cara mengumpulkan seluruh guru yang menjadi sampel pada penelitian ini. Peneliti bersama guru menyusun langkah-langkah yang akan dilakukan, menyepakati aktivitas dan tindakan yang akan dilaksanakan saat kegiatan supervisi klinis. Selanjutnya guru ditugaskan menyusun rencana pelaksanaan pembelajaran disertai dengan media dan alat bantu yang dibutuhkan. Setelah kegiatan awal selesai dilakukan dilanjutkan dengan 
kegiatan mengobservasi guru saat mengajar menggunakan rencana pelaksanaan pembelajaran (RPP) dengan menggunakan pendekatan contextual teaching and learning (CTL) yang telah disusun oleh guru.

Setelah proses belajar mengajar berlangsung peneliti bersama guru mengadakan refleksi untuk memberikan masukanmasukan terhadap temuan yang dijumpai peneliti saat engajar dengan menggunakan pendekatan contextual teaching and learning (CTL). Peneliti memberikan masukan yang sifatnya untuk membangun agar kemampuan guru dalam menerapkan pembelajaran contextual teaching and learning menjadi lebih baik lagi sesuai dengan komponen-komponen yang terdapat dalam pendekatan contextual teaching and learning. Dalam kegiatan ini suasana dibangun dengan senyaman mungkin agar guru yang diobservasi tidak merasa tertekan dengan kegiatan supervisi klinis yang dilakukan. Selanjutnya peneliti memberikan kesempatan kepada guru untuk bertanya terhadap pendekatan contextual teaching and learning yang belum dipahaminya untuk menambah wawasan guru.

\section{Tabel 1. Pembelajaran Siklus I}

\begin{tabular}{c|c|c|c|c|c|c|c}
\hline \multirow{2}{*}{ GURU } & \multicolumn{7}{|c}{ KOMPONEN CTL } \\
\hline & 1 & 2 & 3 & 4 & 5 & 6 & 7 \\
\hline A & & $\sqrt{ }$ & $\sqrt{ }$ & $\sqrt{ }$ & $\sqrt{ }$ & $\sqrt{ }$ & \\
\hline B & & $\sqrt{ }$ & & $\sqrt{ }$ & & $\sqrt{ }$ & \\
\hline C & $\sqrt{ }$ & $\sqrt{ }$ & $\sqrt{ }$ & $\sqrt{ }$ & $\sqrt{ }$ & & $\sqrt{ }$ \\
\hline D & & & $\sqrt{ }$ & & $\sqrt{ }$ & $\sqrt{ }$ & \\
\hline E & $\sqrt{ }$ & & & & $\sqrt{ }$ & $\sqrt{ }$ & $\sqrt{ }$ \\
\hline
\end{tabular}

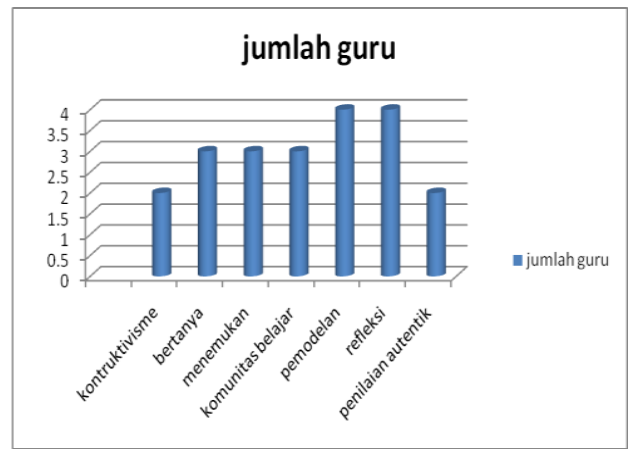

Gambar 2. Pembelajaran Siklus I

Dari tabel dan gambar di atas terlihat gambaran kemampuan guru dalam coba mengintegrasikan komponen CTL dalam proses belajar mengajar setelah mendapatkan supervisi klinis pada siklus I. Dari 5 orang guru terlihat 2 orang guru atau $40 \%$ yang telah mampu melaksanakan pembelajaran dengan melakukan pendekatan kontruktivisme. Tiga orang guru atau $60 \%$ sudah menciptakan proses pembelajaran yang merangsang anak untuk berani bertanya dan mempertanyakan gagasan temannya.. tiga orang atau $60 \%$ guru yang didampingi dalam proses pembelajaran telah menciptakan proses pembeljaran dimana siswa diberikan kesempatan untuk menemukan konsep dan hasil sebuah permasalahan. Tiga dari lima guru atau $60 \%$ dalam proses belajar mengajar dikelas telah membentuk kelompok-kelompok pembelajaran dan dimanfaatkan dalam menyelesaikan permasalahan dalam kegiatan di kelas. Empat orang guru atau $80 \%$ dalam menyampaikan pembelajaran telah melakukan pemodelan, baik yang dilakukan oleh 
guru itu sendiri maupun memanfaatkan orang lain yang memang menguasai bidang yang sedang dipelajari atau dibahas dalam pembelajaran.dari lima guru sebanyak empat orang guru atau $80 \%$ diakhir pelajaran telah melakukan refleksi, dan dari komponen yang terakhir yaitu merancang penilaian yang autentik baru dua orang guru ataau $40 \%$ yang membuat rubrik penilaian sesuai dengan tuntutan penilaian yang autentik.

Berdasarkan hasil observasi dan wawancara pada siklus 1 maka hasil yang diharapkan terhadap lima orang guru yang menjadi sasaran supervisi klinis pada penelitian ini belum sesuai dengan apa yang diharapkan dan sesuai dengan indikator keberhasilan, maka penelitian ini dilanjutkan pada siklus selanjutnya.

\section{Observasi}

Saat proses pembelajaran berlangsung peneliti dengan menggunakan format observasi pembelajaran melakukan observasi yang bertujuan untuk melihat proses pembelajaran contextual teaching and learning yang dilakukan oleh guru. Observasi ini perlu dilakukan untuk mengetahui komponen apa saja yang masih belum dilakukan oleh guru untuk dibwa saat refleksi dan menjadi pembahasan bagaimana cara mengatasinya agar nanti pada siklus berikutnya dapat dilakukan oleh guru. Observasi ini dilakukan dari mulai kegiatan pembelajaran sampai proses pembelajaran selesai.

\section{Refleksi}

Setelah proses pembelajaran berlangsung peneliti dan guru duduk bersama melakuan refleksi dari hasil proses pembelajaran contextual teaching and learning yang baru dilakukan. Refleksi dilakukan berdasarkan lembar observasi yang dilakukan oleh peneliti dan kendalakendala yang dirasakan langsung oleh guru saat mengajar. Refleksi ini bertujuan untuk mengetahui apa kelemahan dan bagaimana cara memperbaikinya agar tidak terjadi lagi pada siklus berikutnya.

\section{Siklus II (Kedua)}

Siklus kedua juga terdiri dari empat tahap yakni: (1) perencanaan, (2) pelaksanaan, (3) observasi, dan (4) refleksi. Kegiatan supervisi klinis yang dilakukan peneliti sama halnya juga seperti yang dilakukan pada siklus I, namun ada beberapa tindakan yang berbeda dilakukan dari siklus I diantaranya dengan membuat guru menjadi tim dalam mengajar. Hal ini dilakukan agar guru bisa mengamati temannya yang sedang mengajar dan dapat melihat kekurangan dan kekuatan temannya saat mengajar dengan menggunakan pendekatan contextual teaching and learning (CTL). Segala kekurangan yang dilihat guru hendaknya dapat diperbaiki guru saat nantinya dia mengajar, sedangkan kekuatan yang dimiliki oleh temannya diharapkan dapat diduplikasi guru saat mengajar, bahkan kalau bisa lebih ditingkatkan lagi. 
Hasil observasi pada siklus kedua terlihat pemahaman dan kemampuan sembilan orang guru dalam melaksanakan pembelajaran yang menerapkan CTL sudah lebih baik dari siklus I. Seluruh komponen yang menjadi aspek dari pembelajaran CTL telah coba dilaksakan guru dalam kegiatan belajar mengajar. Hasil observasi tentang pelaksanaan pembelajaran yang menerapkan komponen CTL adalah sebagai berikut:

Tabel 2. Pembelajaran Siklus II

\begin{tabular}{c|c|c|c|c|c|c|c}
\hline \multirow{2}{*}{ GURU } & \multicolumn{7}{|c}{ KOMPONEN CTL } \\
\cline { 2 - 8 } & 1 & 2 & 3 & 4 & 5 & 6 & 7 \\
\hline A & $\sqrt{ }$ & $\sqrt{ }$ & $\sqrt{ }$ & $\sqrt{ }$ & $\sqrt{ }$ & $\sqrt{ }$ & $\sqrt{ }$ \\
\hline B & $\sqrt{ }$ & $\sqrt{ }$ & $\sqrt{ }$ & $\sqrt{ }$ & $\sqrt{ }$ & $\sqrt{ }$ & $\sqrt{ }$ \\
\hline C & $\sqrt{ }$ & $\sqrt{ }$ & $\sqrt{ }$ & $\sqrt{ }$ & $\sqrt{ }$ & $\sqrt{ }$ & $\sqrt{ }$ \\
\hline D & & $\sqrt{ }$ & $\sqrt{ }$ & $\sqrt{ }$ & $\sqrt{ }$ & $\sqrt{ }$ & \\
\hline E & $\sqrt{ }$ & $\sqrt{ }$ & & $\sqrt{ }$ & $\sqrt{ }$ & $\sqrt{ }$ & $\sqrt{ }$ \\
\hline
\end{tabular}

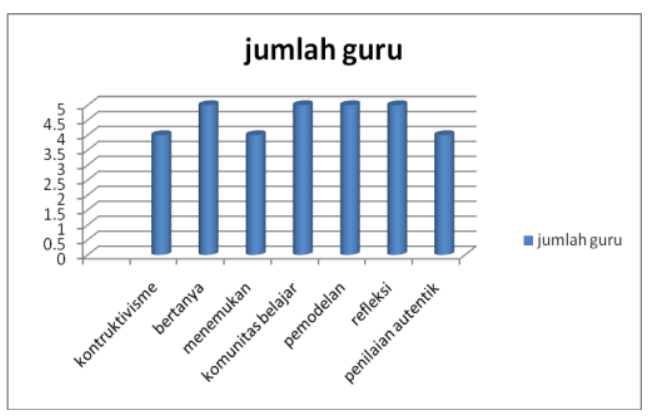

Gambar 3. Pembelajaran Siklus II

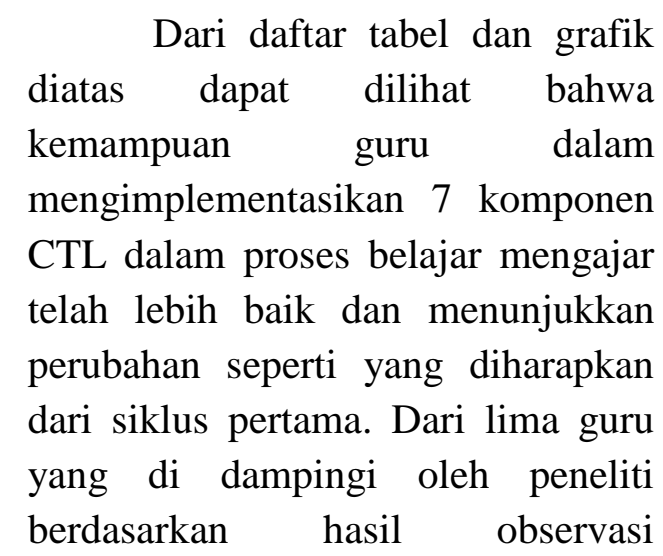

pembelajaran dan wawancara setelah selesai kegiatan supervisi klinis empat dari lima guru telah memahami dan dapat menerapkan pembelajaran CTL dalam proses pembelajaran yang dilaksanakannya di dalam kelas, hanya satu orang guru yang masih mengalami kesulitan dalam hal merancang proses belajar mengajar yang mencerminkan pembelajaran yang konstruktivisme serta bagaimana merancang penilaian yang autentik. Berdasarkan gambaran yang dilihat peneliti yakin bahwa dengan semangat dan keinginan belajar yang dimiliki oleh guru tersebut, maka guru tersebut dalam waktu dekat telah mampu melaksanakan proses pembelajaran yang mencerminkan pembelajaran yang kontekstual.

\section{Observasi}

Saat proses pembelajaran pada siklus II berlangsung sama seperti pada siklus I peneliti dengan menggunakan format observasi pembelajaran melakukan observasi yang bertujuan untuk melihat proses pembelajaran contextual teaching and learning yang dilakukan oleh guru. Observasi ini perlu dilakukan untuk mengetahui komponen apa saja yang masih belum dilakukan oleh guru untuk dibawa saat refleksi dan menjadi pembahasan bagaimana cara mengatasinya agar nanti pada siklus berikutnya dapat dilakukan oleh guru. Observasi ini dilakukan dari mulai kegiatan pembelajaran sampai proses pembelajaran selesai. 


\section{Refleksi}

Setelah proses pembelajaran pada siklus II selesai, peneliti bersama guru yang dibimbing melakukan kegiatan refleksi untuk melihat hambatan dan kendala yang masih dirasakan oleh guru dalam menerapkan pembelajaran contextual teaching and learning di dalam kelas. Refleksi dilakukan mengacu kepada lembar observasi dan hasil pengalaman langsung guru yang dibimbing saat mereka melakukan proses pembelajaran contextual teaching and learning di dalam kelas.

Hasil refleksi yang dilakukan pada siklus II sudah berbeda jauh dengan hasil refleksi yang dilakukan pada siklus I.Dari lima orang guru hampir semua guru sudah mampu mengimplementasikan komponen CTL dalam proses pembelajaran, hanya satu orang guru yang masih sedikit mengalami kendala dalam membuat rubrik penilaian.

\section{Pembahasan}

Pada awal kegiatan penelitian saat pra siklus ketika peneliti melalui kegiatan wawancara bertanya kepada ke lima orang guru tentang apa yang dimaksud dengan pembelajaran yang kontruktivisme dan bagaimana pelaksanaanya di dalam kelas, tidak satu orang gurupun yang mampu menjelaskan dan memberikan contoh pelaksanaannya dalam proses belajar mengajar. Setelah siklus I dilakukan, dua guru atau $40 \%$ telah mampu merancang pembelajaran yang mencerminkan pembelajaran yang konstruktivisme, sedangkan tiga orang guru atau $60 \%$ masih belum memahami tentang pembelajaran yang kontruktivisme. Setelah dilakukan supervisi klinis pada siklus dua, maka terjadi peningkatan. empat guru atau $80 \%$ guru telah memahami tentang pengertian dan pelaksanaan kegiatan yang mencerminkan pembelajaran yang kontruktivisme dalam pembelajarannya. Terjadi peningkatan $40 \%$ untuk komponen konstruktivisme ini.

Pada siklus pertama tiga orang guru atau $60 \%$ telah merancang proses pembelajaran yang dapat memicu agar siswa aktif untuk bertanya dan mempertanyakan gagasan temannya, hanya dua guru atau $40 \%$ yang belum mampu melakukannya. Setelah dilaksakan kegiatan supervisi klinis pada siklus II, seluruh guru atau $100 \%$ telah coba menciptakan kegiatan pembelajaran yang mampu merangsang siswa untuk berani bertanya.Untuk komponen bertanya ini terjadi peningkatan $60 \%$ dari siklus I.

Pada siklus pertama tiga orang guru atau $60 \%$ telah mencoba dalam pembelajaran menciptakan aktifitas pembelajaran dimana siswa diharapkan dapat menemukan solusi dari permasalahan yang sedang dibahas, sementara dua orang guru atau $40 \%$ belum mampu melakukan kegiatan tersebut. Setelah supervisi klinis pada siklus II dilakukan empat guru atau $80 \%$ telah mencoba memberikan kesempatan siswa untuk menemukan solusi atas permasalahan yang sedang dibahas. 
Terjadi peningkatan $40 \%$ untuk komponen menemukan dari siklus I.

Pada siklus pertama tiga orang guru atau $60 \%$ dalam proses belajar mengajarnya telah memanfaatkan kelompok kelompok siswa, namun ada dua orang guru atau $40 \%$ yang masih membuat kelas konvensional dengan alasan jumlah siswa yang tidak sesuai dengan lokasi kelas. Setelah dilakukan supervisi klinis pada siklus II seluruh guru atau $100 \%$ guru yang menjadi binaan peneliti telah melaksanakan pembelajaran kooperatif dengan cara memanfattkan kelompok kelompok diskusi dalam proses pembelajaran. Jika dipersentasekan, $100 \%$, terjadi peningkatan $40 \%$ dari siklus pertama.

Pada siklus pertama empat orang guru atau $80 \%$ telah melakukan pemodelan untuk menjelaskan dan memberikan contoh terhadap materi yang sedang disampaikan, hanya satu orang atau $20 \%$ yang masih belum. Setelah dilakukan supervisi klinis pada siklus II maka seluruh orang guru atau $100 \%$ telah melakukan pemodelan untuk memperjelas pemahaman siswa terhadap materi yang sedang dipelajari.

Pada siklus pertama empat

orang guru atau $80 \%$ telah melakukan refleksi daiakhir kegiatan, hanya satu orang guru atau 20\% yang tidak sama sekali melakukan refleksi dengan alasan keterbatasan waktu yang tersedia. Setelah diberikan supervisi klinis pada siklus II seluruh guru diakhir pembelajaran melakukan refleksi bersama-sama dengan siswa untuk melihat sejauh mana pencapaian konsep materi yang baru dipelajari. Jika dilahat peningkatan dari siklus I terjadi peningkatan $20 \%$.

Pada siklus pertama hanya dua orang guru atau $40 \%$ yang telah melakukan penilaian secaraa autentik. Guru telah mempersiapkan rubrikrubrik yang diperlukan untuk melakukan penilaian terhadap materi yang akan diajarkan. tiga orang guru atau $60 \%$ belum melaksanakan penilaian yang autentik dengan alasan sulit merancang rubrik penilaian yang menjadi tuntutan penilaian yang autentik. Setelah dilakukan supervisi klinis pada siklus II empat orang atau $80 \%$ telah melakukan penilaian yang autentik setiap mengakhiri proses pembelajaran. Terjadi peningkatan $40 \%$ dari siklus I.

Dari rangkaian Uraian di atas terlihat terjadi peningkatan yang sangat berarti dari lima orang guru yang menjadi sampel pada penelitian tindakan kelas ini dalam upaya melaksanakan pembelajaran Contextual Teaching and learning dalam proses pembelajaran di kelas. Jika diawal kegiatan dari lima orang guru mereka tidak paham sama sekali tentang pembelajaran kontektual.

\section{Pembahasan}

Berdasarkan data di atas, dan ditambah dengan hasil wawancara yang dilakukan dengan guru yang didampingi lima orang atau $100 \%$ mereka telah paham tentang 
pembelajaran contextual teaching and learning, dapat diambil kesimpulan bahwa dengan kegiatan supervisi klinis dapat meningkatkan komitmen guru dalam menerapkan pembelajaran Contextual teaching and learning (CTL) di SMP Negeri 2 kota Tebing Tinggi dan penelitian ini dikatakan berhasil.

\section{SIMPULAN}

Berdasarkan hasil Penelitian tindakan sekolah (PTS) dapat disimpulkan bahwa supervisi klinis yang dilaksanakan peneliti dapat meningkatkan kemampuan guru dalam melaksanakan pembelajaran Contextual teaching and learning (CTL) di SMP Negeri 2 kota Tebing Tinggi, hal ini dapat dilihat dari lima orang guru yang didampingi empat guru atau $80 \%$ telah mampu melaksanakan pembelajaran yang menerapkan 7 komponen CTL. Selain itu hasil wawancara yang dilakukan diakhir siklus II seluruh guru yang didampingi atau 100\% telah memahami tentang pembelajaran kontektual, walaupun dalam pelaksanaannya masih ada satu orang yang mengalami kedala dalam menerapkan pembelajaran kontruktivisme dan penilaian autentik, namun secara teori guru tersebut telah paham. Berdasarkan 2 alasan tersebut maka peneliti mengatakan bahwa penelitian ini berhasil.
a. Supervisi klinis dapat meningkatkan pemahaman guru terhadap komponen komponen yang menjadi ciri pembelajan

kontekstual. Ke tujuh komponen CTL dengan kegiatan supervisi klinis yang dilakukan oleh peneliti dapat dipahami oleh guru dan dapat diimplementasekan dalam proses belajar mengajar di kelas khususnya pada pelajaran bahasa Inggris.

\section{DAFTAR RUJUKAN}

Arikunto, Suharsimi. 2003. Manajemen Penelitian. Jakarta: Rineka Cipta.

Amri. 2010. Media Pembelajaran. Jakarta: Raja Grafindo Persada. Duysens, J., \& Pearson, K. 1980. Inhibition of flexor burst generation by loading ankle extensor muscles in walking cats. Brain research, 187(2), 321-332.

Hamalik, Oemar. 2003. Kurikulum dan Pembelajaran. Jakarta: Bumi Aksara.

Sugiarti, T. 1997. Penelitian Tindakan Kelas. Makalah disampaikan pada Pelatihan Peningkatan Kualifikasi Guru S1 PGSD. Universitas Jember. Jember.

Syah, M. 1995. Perkembangan Pendidikan. Bandung: Rosdakarya. 